\title{
Enclosed Self-introspection and Camouflage: Interior Monologue in Republican Chinese Women's Epistolary and Diary Writing
}

\author{
Liu Yixin \\ Department of Asian Studies, The University of Edinburgh, Edinburgh, UK
}

Email address:

1470532215@qq.com

To cite this article:

Liu Yixin. Enclosed Self-introspection and Camouflage: Interior Monologue in Republican Chinese Women's Epistolary and Diary Writing. International Journal of Literature and Arts. Vol. 9, No. 2, 2021, pp. 70-78. doi: 10.11648/j.ijla.20210902.14

Received: March 21, 2021; Accepted: March 31, 2021; Published: April 13, 2021

\begin{abstract}
In Republican women writers' works, the diary and epistolary modes are two common styles to reveal characters' interior monologue (IM) and the flow of consciousness in fiction. The women writers often attempt to convey the self-introspection with female awareness through both narrative forms; in particular, women writers use it to express the narrator/characters' IM in a private enclosed situation. Through the specific textual analysis, it can be seen that the authors attempted to imply something through both of these narrative forms; in particular, women writers used this as a way to express the characters' IM in private situations; for another thing, the usage of epistolary or diary forms could enable women writers to avoid possible criticism or blame when they tried to express their feminist feelings or thoughts. To some extent, this private narrative form provided an existential space for their discourse. No matter for the diary or the letter, seemingly it is merely a personal expression of thoughts and emotion, however in fact this was women writers' intentional choice. They clearly knew that female writing was not yet the established norm, so most of women writers showed cautiousness in their creative writing. It achieves a more effective negotiation with a patriarchal society.
\end{abstract}

Keywords: Women's Literature, Interior Monologue, Epistolary and Diary Writing, Patriarchy

\section{Introduction}

In Republican women writers' works, the diary and epistolary modes are two common styles to reveal characters' interior monologue (IM) and the flow of consciousness in fiction. In this selection of short stories, the form of diary or epistle acts as the medium to provide authors a space for showing the narrator/protagonists' IM. Before analysing this sort of writing with specific texts, I will explore why some Republican Chinese women writers wrote in this way.

As mentioned above, some diary or epistolary short stories are organised with narrator/protagonists' IM. In this type of text, the story plot can be weakened, arranged based on narrator/protagonists' psychological activities.

Lu Xun's "Kuangren riji" (Diary of a madman, 1918) has been regarded as the first short story in modern Chinese literature that reveals the character's interior monologue in the form of series of diaries, thereby conveying the madman's inner thoughts and feelings. Within these thirteen diary entries, ten of them feature the protagonist's interior monologue, in which there is neither much story plot nor details about characters and surroundings. In Western literature, The Sorrows of Young Werther (Die Leiden des Jungen Werthers), for example, is a typical epistolary novel. Although it seems that Werther has always been writing to a certain person, the contents of these letters are actually the protagonist's IM with the illogical and aimless flow of consciousness. According to Amy Dooling, the letter form in Republican literary field gained initial popularity after Guo Moruo translated Die Leiden des Jungen Werthers into Chinese in 1921. [1]

Compared with epistolary literature, diary literature is presented as more personal and more closed as it is supposedly not open to other people than the writer; however, since many authors choose to allow their diaries to be published, it means that the author hopes that it can be read by the public rather than only himself or herself. Therefore, this narrative form is somehow a disguise, and there should exist something that the author wants to imply behind this form. Similarly, the letter 
theoretically should only have one recipient, and neither the author nor the recipient should share the contents of letters with the public.

Generally speaking, the letter is a very private and intimate form of dialogue taking the middle position between "communication et non-communication, entre solitude et solidarité, entre isolement et échange". [2] During the Republican period, especially the May Fourth era, women writers not only contributed to a large extent to the production of the astoundingly extensive body of epistolary literature, but they also determined the development of this genre more often and to a higher degree than has been thought so far. In addition, this narrative format has a typical dialogic nature, which encourages the establishment of dialogue between the implied author, narrator/character, implied reader and the reader.

Hence, for one thing, we should point out that the format itself is not exclusive to female authors. These two forms of narrative fiction were prevalent among male and female authors. But it often appears to become as a prominent "modern" narrative practice in relation with "New Women" (xin nüxing) in early republican China, which is representative of their repositioning as social subjects. The women writers often attempt to convey the self-introspection with female awareness through both narrative forms; in particular, women writers use it to express the narrator/characters' IM in a private enclosed situation.

For another thing, the usage of epistolary or diary forms may enable women writers to avoid the possible criticism or blame when they try to express their emotional feelings or thoughts with female awareness. To some extent, this kind of private narrative form provides an existential space for their discourse. Under this peculiar protection, or perhaps say, the deliberate camouflage, characters' IM can be conveyed more fully and incisively. In other words, no matter for the diary or the letter, seemingly it is merely a personal expression of thoughts and emotion, however in fact this was women writers' intentional choice. They clearly knew that female writing was not yet the established norm, so most of women writers showed cautiousness in their creative writing. It achieves a more effective negotiation with a patriarchal society.

They managed to find an appropriate space for themselves so as to convey their ideas freely. As Amy Dooling argues, this kind of narrative strategy seems to "temper the harsh impact of an impersonal third-person narrativisation of the wrongs inflicted on women in patriarchal culture". [1]

\section{The Diary as Modern Reconstruction: Lu Yin's Pursuit of Free Love}

As Cynthia Huff points out, diaries speak to us without the need of a mediator, an authority who can initiate us into the mysteries of the text. She notes that diaries are accessible not exclusive, comprehensible not arcane, and in their very accessibility, they establish ties between the reader and the writer. [3] We can see that the connections intrinsic to this kind of form are many, joining us to our past selves or prospective identities, and our roots in a collective yet differentiated women's past and so forth. Additionally, this narrative form has not borne the exclusive mark of authority; the contents also do not need to be explicated. Hence, "their inherent generic qualities are subversive to the literary establishment and to the patriarchal social order that it perpetuates in its privileging of texts and genres, each ranked according to unquestioned standards". [3]

Thereby, on the other hand, the diary literary form has always been accused of looseness and a lack of rigour by some male critics, while some feminist critics hint that this form contains the key to the revision of the canon, to female aesthetic manifesting "an emotional texture, a structural expression of mutuality". [6] For example, in Virginia Woolf's The Second Common Readers, she illustrates the diary form as a feminist practice. [4] For Woolf, the literature in diary form is mysterious, because the connections that it establishes are enigmatic, not the intentional molding of art or of criticism, the shutting-out of possibilities in the effort to distinguish the easily identifiable patterns of meaning. [4]

During the Chinese Republican period, women writers contributed to a large extent to the production of an extensive body of the diary genre. Apart from Ding Ling whose "Shafei nüshi de riji" (Miss Sophie's diary, 1927) has been mentioned regarding its "self-absorbed stream of consciousness" as well as characters' internal minds [5] Lu Yin was also a prominent writer who always reveals the protagonist's aimless IM and the flow of consciousness with fragmentary diary episodes, much like "Kuangren riji". Her short story "Fuqin" (Father, 1925), for example, consists of thirteen discontinuous diary entries, in which the son (the diarist) falls in love with his shumu (concubine mother) and expresses his intense dissatisfaction with his father, thereby revealing the normal domestic life dominated by his father. Typical of Lu Yin's female protagonists, the image of shumu is highly sentimental, her feminine suffering, frailty, and illness reminiscent of the "sorrowing and ailing" (duochou duobing) of female characters in Chinese traditional fiction. [6]

To be specific, according to what the son (the protagonist) writes in his diaries, his birth mother married his father when she was seventeen years old; because of his father's ongoing whoring and gambling, his mother eventually died of consumption. Soon afterwards, the father married a prostitute who is now the narrator's stepmother, and then they had a child. Yet, on a business trip, the father married another girl, and deceived her into believing that he would like to live with her at her home and thus she becomes the protagonist's shumu.

So, for ten years, his shumu has been deceived into thinking she is the only wife of his father; however, in fact, the older wife, the protagonist's stepmother, was living in another province, and she is depicted as a quintessential bad woman: an "acrimonious, mean, and ... ugly" former courtesan. [7] Soon after the protagonist returns to his father's house after a long absence, his stepmother suddenly moves in as well, lays claim to the position of principal wife, and loudly berates her husband for taking a concubine on the sly. While she rants and raves, the shumu, in "opposite" fashion, retires to her own 
room to grieve quietly over the deception and the revelation of her lowly status as a secondary wife. Then, shumu becomes ill under the strain and requests permission to leave and set up a house of her own. Dramatically, her move brings an unexpected stroke of luck for the protagonist because his father assigns him to live with his shumu and look after her. During the period they stay together, he searches desperately for an opportunity to express his love, and one day he presents her with a bouquet of red roses. Already in failing health, she suffers a nervous collapse upon grasping his meaning and is bedridden. The protagonist is terribly distressed that his gift precipitated this attack, but she soon calls him to her bedside to tell him that only his father is to blame for her wretched state rather than him or others. Several days later, they exchange kisses and confessions of love, and she dies peacefully. She is buried under a tombstone of her own choosing that is engraved with her name and a likeness of Cupid. At last, the diary ends with the protagonist's resolution never to return to his father's house.

At the beginning of the first diary, the protagonist recalls the scene where he accidentally saw his shumu doing her make-up beside the window; it is obvious to see his inner constraint and uneasiness due to his improper feelings for her. In the passage below, the italics are his inner emotional thoughts, while the rest of sentences are his statements of reality:

Oh! So beautiful! [...] I'm the bravest man in the world! I couldn't admit it. Normally. But! At this moment, my heart cannot be hidden. [...]

Here I am writing on and on-so, who is she, after all? Oh dear! I feel myself blush. According to reason, I shouldn't love her. But... who decided what is reasonable? Why did the gods give me this pair of eyes and cause me to take a fancy to her? She's my father's wife! Doesn't that make her my mother? It should be quite normal that a son loves his mother! Oh! NO! Huh! It should be quite normal that a son loves his mother! Oh! NO! Huh! If someone criticised me like this, it could be said that he or she didn't know about me at all. My mother-my birth mother-has already passed away. My love for a mother has been taken away! How can I recognise this woman as my mother? She's only two years older than me! How? How can she be my mother? What a joke![7]

Although there should be no audience other than the diarist himself for his written diary, it seems that an implied reader exists to form a kind of dialogue with the narrator. From the perspective of narrative time, there exists a kind of gap between the narrative self and experienced self. Although it seems that the diarist is writing what happened this day or the previous day, his emotion inclines to narrate the experiences of "I". Thus, the narrated present should be the "experienced present" that the narrator experienced before, and thereby the process of his writing is also an exploration to examine himself.

Through his personal confession, we can see that the incestuous nature of the romance between them is at least explicit. The diarist is tormented by the knowledge that the woman he loves is his the so-called "mother" and returns to the problem obsessively. Even when his friends come to visit him, he also feels uneasy (italics):

This afternoon, a friend stopped by for a visit. His sharp eyes circled around me. That's so weird. Was he aware of it? No! It couldn't be! Everybody knows that she's my father's wife! I'm like such a thief! I thought like this and laughed at myself. People are really stupid! [7]

When he searches for the opportunity to express his love for her, some mind still tortures him. In his opinion, it is his father that resists him from loving her. So, he regards his father as a thorn in his side. [7]

In a sense, these series of self-conscious musings draw awareness to the forbidden nature of the male protagonist's love for his shumu as well as to his rivalry with his father. His protest against "the seemingly autocratic rules governing interaction in the patriarchal family" zeroes in on the taboo against the incest of the so-called mother and son. [6]

Structurally speaking, "Fuqin" is a story within a story. We can see that the story proper is a rather typical oedipal romance, and as Lieberman notes, it can be said that this short story is one of the first oedipal works of fiction in Chinese. [6] To some extent, this story demonstrates that women can also write men's stories, but its importance in taking a feminist position does not stop there.

In the end, shumu dies of serious melancholia. In her last moments, she says to the narrator that "actually I did not fall in love with your father when we married. Unfortunately, I am a woman and I can do nothing about my marriage." [7] Meanwhile, she expresses her disappointment with men- "some people persuaded me to divorce with your father but I didn't think it beneficial to me because men rarely can be relied on". [7] With growing disillusionment with the father, shumu struggles between hope for the narrator and desperation of reality. What she expresses reveals familial oppression of women in a patriarchal society and breaks the enchantment of loving relationships in a male-dominated world. At the same time, although her death is tragic, it indeed fulfils certain fantasies that the lovesick protagonist has already expounded in several previous diary entries: it is noble to die for love; she is the "goddess of love". [7] As a result, it can be said that her aestheticised sacrifice offers testament both to her love for the male protagonist and to her unjust treatment at the hands of the patriarch. [6]

In addition, although her death leaves the son heartbroken and feeling like a "walking corpse", [6] it also frees him finally from his father. Meanwhile, the son, as the central role in this story, directly exposes father's immortal behaviour, which transcends conventional cardinal guides. Normally, no matter what a patriarch did in the family, the junior generation had no right to condemn it; however, in "Fuqin", the narrator expresses his dissatisfaction with his father without any disguise. The narrator in it depicts his father as a "ridiculous old grouch" and even he says that "without moustache, he still looks old because of the line at the corner of his eyes and of forehead". [6] As a son against the traditional patriarch's claim to his concubine or to other families, the narrator does not preserve the dignity of his father and tramples upon his 
authoritative father-like image. This kind of counter-familial narrative subverts phallocentrism and there appears to be a rupture within conventional male discourse. Lacan locates the man in a phallocentric subject position from a symbolic perspective, while the woman is situated on the edge. [8] Under phallocentrism, male superiority in the traditional family existed for a long time and thus female discourse was constrained all the time.

Apart from "Fuqin", "Lishi de riji" (The diary of Lishi, 1923) is another of Lu Yin's diary-style short stories interweaving extensive use of IM. [9] This first lesbian novel amongst May Fourth female literature was originally published by Xiaoshuo yuebao (Short story monthly) in 1923 and constitutes sixteen diary entries by a female student, Lishi before she died. Compared with the other two May Fourth lesbian stories by women writers, Ding Ling's "Shujia zhong" (During summer vacation) and "Shuoyou zheme yihuishi" (There is one thing) by Ling Shuhua, [11] published in 1926 and in 1928 respectively, "Lishi de riji" received great attention when published and has been considered a great challenge for orthodox ethical heterosexuality. [12]

The female protagonist, Lishi, is dissatisfied with the monotony of school life, as well as with her hypocritical male teacher; meanwhile, she feels upset for the miserable marriage life of her friend, Wenwei. Accordingly, she pushes away the opposite gender and gradually finds herself unwilling to get close to men. "I never want to seek comfort from the opposite sex because it makes me feel unfree to be together with them." [9] Lishi has a girlfriend, Yuanqing, with whom she enjoys romantic love and they plan to live together, and even to get married in the future. However, Yuanqing's parents eventually oppose the love between Lishi and Yuanqing, and Yuanqing's mother wants to leave for Tianjin with her to attend a relative's wedding. Yuanqing then is forced by her mother to move to Tianjin and to date her cousin as a prelude to their marriage. Finally, Yuanqing is compelled to marry her cousin and Lishi loses her will to live and soon dies of melancholia.

Compared with the son's IM in "Fuqin", Lishi's IM is more like the inner outburst with rage and condemnation of not only those who oppose her love with Yuanqing but also the decaying social system with its so-called "Confucian virtue and morality". [13] For example, when Lishi receives a letter from Yuanqing about her leaving for Tianjin, Lishi feels despair, and in her eyes, all of the people who oppose them are their enemies:

Humans! So stubborn, so selfish! Our frail lives are completely dominated by them! They're like thieves! Our ideal life cannot be tolerated at all!

Ugh! Oh! The feelings of humans! So easily changed. After no more than half month, Yuanqing has been taken away...

Human life! Struggling may be our first condition! [9]

Through this passage of IM, it can be seen that Lishi's emotion towards Yuanqing is intense, and her decision to fight for their free love is not only for themselves but also a sort of challenge to the social system.

Here, it is noteworthy that in the fragments above, the narrative voice shifts from personal voice into the communal voice unexpectedly, and this is the only IM passage with communal voice in the short story. As a crucial notion of feminist narratology, narrative voice is considered as "a trope of identity and power" for the personally and collectively silenced. [14] Among the three types of narrative voices proposed by Susan Lancer, the communal voice "articulates either a collective voice or a collective of voices that share narrative authority", [14] and thus it facilitates the achievement of the female protagonists' speaking authoritative subjectivity.

In most parts of the short story, the narrator is "I", while in these two passages, the narrator becomes "we" ("our"). The diary seems no longer written for the narrator herself. Although seemingly "we" refers to Lishi and Yuanqing, in fact it stands for females as a whole. At that time, there were many women suffering from the same ordeal: free love and marriage was only a slogan, and lesbian relationships were practically unknown. Apart from "we" ("our"), in the passage there appear other plural nouns "humans" and "they". In this way, those narrative conventions that deter the construction of both female communities and communal voice are negotiated in a proper way. Lishi writes from the perspective of the collective consciousness, and meanwhile it reflects the intensity of her resistant awareness.

However, unlike Lishi, Yuanqing is apparently resigned to her parents' arrangement. She writes in her letter that "...we have to break up now... Ah, Lishi! Why didn't you plan ahead! Why didn't you dress up in men's clothes, put on a man's hat, act like a man, and visit my parents to ask for my hand? Now they know you're a woman, and they will not let you marry me." [14] What Yuanqing says reveals that homosexuality cannot be accepted by society unless it is camouflaged as heterosexuality. In other words, normally women fail to subvert conventional gender orders in the process of deconstructing binary sex-based relationships with self-consciousness. Attitudes towards the "Other" could not be prepared to break through the dualistic ethical imperative within traditional morality, as it would destroy Confucian kinship structures and separate the spheres of gender and infringe on a series of ethical ideologies. Additionally, it would be impossible to establish the patriarchal cultural system in an incomplete modern society. In Butler's eyes, those who are opposed to heterosexual culture and were identified as "abnormal" should be at the same stage. [15]

In this story, the neologism "same-sex romantic love" (tongxing de ailian) is used to indicate Lishi's awareness of the concept of homosexuality, and physical lesbian desire "gains a highly symbolic visibility" appeared in her dream which is one scene depicted in the narration, to reveal how lesbianism envisions their common married life. [16] Therefore, even though apparently Lu Yin advocated spirituality in lesbian love, she has nonetheless conveyed her idea of attraction between female bodies as well, and she sought a reasonable existence for female physical desire in lesbian relationships. Lu Yin combined lesbian spirituality and lesbian sex closely; these two seeming antitheses are in essence related to the deconstruction of the conventional 
gender order. As Butler points out:

The construction of coherence conceals the gender discontinuities that run rampant within heterosexual, bisexual, and gay and lesbian contexts in which gender does not necessarily follow from sex and desire... When the disorganization and disaggregation of the field of bodies disrupt the regulatory fiction of heterosexual coherence, it seems that the expressive model loses its descriptive force. [15]

When realising the customary gender order is being broken and the heterosexual mode is being disrupted, the individual's gender identity in terms of the inner truth of gender will progressively turn into "integrity" or cause self-disavowal. For example, Yuanqing in this story plays a role with personal anxiety and is inscribed with exterior impacts. Although she realises her real sexual orientation, she is still able to "act" as a "real woman" [15] at the end. Through "stylised repetition of acts",[15] her gender is instituted in outer space, which in essence leads to the final failure of her lesbian love with Lishi. Her mother repeatedly stresses that she should be a real woman who is supposed to marry a man rather than a woman. Compared with Lishi, Yuanqing receives more regulation and instigation of behaviour in terms of what to do and how to "act" as a female being. Therefore, even though Yuanqing admits her love for Lishi, she does not totally exclude the opposite sex and even accuses Lishi of being a woman rather than a man. [9] Eventually, she writes a letter to Lishi and advises her to abandon lesbian love, "Lishi, our previous thoughts were indeed juvenile and immature. Same-sex love cannot be accepted by the public and I hope you can come to your senses and correct your mistake!" [9]

Eventually, she reaffirms binary gender relationships as well as heterosexual ethics. In this sense, Yuanqing's gender identity is more established socially and temporally, which in essence fails to transcend the normative gendered sex. By contrast, without too much kin interference, Lishi claims her exhaustive disavowal of heterosexuality and breaks through the binary two sexes. For the sake of comforting Lishi, Yuanqing introduces another young man, Liwen, to her, which annoys Lishi a lot. She expresses her deep resignation about it—-How could Yuanqing do this to me?" [9]— and feels she is being insulted by her pure love. In the final diary entry, Lishi's IM reveals her intense sorrow:

Ugh! I don't hate anything else! I just hate... hate that God didn't treat human beings equally when creating us... I hate... hate that a difference between men and women exists. Such a peaceful world has been messed up! Ah! I'm even more miserable! Why? Why did I choose to love Yuanqing?

For the sake of Yuanqing, I've lost the joy of my life! I've fallen into a hopeless muddle!

God! I hope you take me away as soon as possible!

God... [9]

That Lishi's love for Yuanqing does not transform with the involvement of the opposite sex suggests that the inner truth of gender cannot be found "in the arbitrary ground" [15] and reveals that most real lesbians avoid men and "there is a feeling of resentment". [17] Moreover, the characterisation of Lishi implies the author's perception in terms of gender difference. Lu Yin always emphasises that "they (women) must be not merely women but also people" [18] and believes that the difference between men and women would only be based on the person rather than on two-sex characteristics. In other words, as Butler advocates, gender difference is not natural and can be constituted. [15]

Eschewing depictions of voluptuous women's bodies and vivid sexual descriptions, Lu Yin's narrative deconstructs the conventional binary gender order with the angle on female ideological transformation. Lu Yin's response to the issue of homosexuality is to immerse her female protagonists in a solitary vacuum in which women are able to thoroughly examine their own emotional status and not to be violated at all. In this process, the form of diary acts as an appropriate cover for this vacuum world, creating a secret base for her. Because seemingly it is just a diary that someone writes for herself, and it is the personal belongings. Under the protection, the narrator can express herself safely; meanwhile, the discourse right of author herself is protected as well.

In Western literary criticism, diaries are often referred to as women's traditional literature, presumably because they were the only form of writing women were traditionally allowed to practice. For example, Leonore Hoffman underscores the accepted reason for reading women's diaries by saying that these are the only means by which we can reconstruct many women's uses of language. She specifically renounces any claim of literary merit in the genre. Her tacit assumption of the diary's inferiority is echoed by Elaine Showalter and by Sandra Gilbert and Susan Gubar as well. [19]

Similarly, in traditional Chinese literature, the diary genre was not traditionally widely recognised as having great literary merit and was classified as marginal discourse, because it was excluded from the artistic hierarchy and standard forms of communication. [22]

Nevertheless, we are not supposed to completely deny the values of this undervalued mode. As Woolf realises, neither the writer, the reader, nor the critic should play the part of a censor, cutting herself off from the discovery of new meanings. "Significance lies not where we expect it but where we have never seen it before". [3] Lu Yin practises her reconstruction of diary in a modern way, and she takes advantage of the diary form to break through the margin, to meld the inner with the outer, and to connect reality and fiction.

\section{Rewriting the Letter: Women Writers' Epistolary Monologue}

Although not a mainstream mode in modern literature, the epistolary narrative was increasingly taken up by early twentieth-century writers to represent marginalised figures who were silenced or unable to openly tell their stories - most frequently women. Women have often been viewed as superior letter writers due to the alleged "naturalness" spontaneity, as well as the greater expressiveness of their style. 
[23] Their empathy for the letter genre was not only beneficial from stronger emotional sensitivity but was also the result of their passive existential status in society.

Their practice of epistolary writing also provides significant insights into transforming gender stereotypes and shifting cultural recognition of gender-genre connections. In addition, apart from conveying the character's interior monologue, this kind of narrative mode has typical dialogic nature, which encourages the establishment of dialogue not only between the narrator/character, the implied reader and the reader.

"Huoren de bei'ai", [24] for instance, is written in epistolary form. The female protagonist Yaxia writes several letters to her best friend, KY, to describe her romantic encounters with men and to express her inner thoughts about the love between them, although they end in failure. Meanwhile, Yaxia also writes about several similar misfortunes of her other friends in their love relationships. Yaxia believes that a woman is supposed to enjoy pleasure through romance; however, in the end, she commits suicide since what she dreams about is no match for the powerful social conventions that expect a woman to commit herself to a male-centred relationship. To some extent, what Yaxia embraces in her mind reflects the author's philosophy of carpe diem, which in fact is based on Lu Yin's understanding of women's existential dilemmas. Meanwhile, she reminds contemporary women to build up an independent personality and that they should not be a "vase" serving as a man's plaything and should not lose self-respect in romantic relationships either. In Yaxia's final letter to KY, a long passage of her interior monologue is impressive:

The world is unable to find the truth. Why work hard? There's no more important thing in life than death! No. I am not afraid of death! What else will I fear? Ah! Now! I'm almost submerged in the dark sea... When I felt extreme sorrow, I wanted to commit suicide; however, I had no courage! I denied the whole world! I attempted to practise my carpe diem philosophy, but I failed at the first attempt! How? How can I practise it? I'm just being tricked by this world... I cannot succeed alone. How? How could I not despair? Ugh! God! My incurable insomnia is back! My heart disease is back! Oh. Now. No. I'm going to die! [24]

At last, this short story ends with a note written by the cousin of the original letter writer Ya Xia, who collects her letters and diary after Yaxia's suicide and sends them to KY, thereby connecting the life of the recipient with its sender.

Similarly, "Shengli zhihou" (After victory, 1925) also has a frame for the featured long letter, further opening up the space of the narration. [25] As Jin Feng points out, Lu Yin's fictional private letters extend the communication beyond the two people directly engaged in correspondence, and she typically wove many women's names and lives into her epistolary fiction. [26] Therefore, we can see that not only do her works highlight women's group activities but to some extent, they also develop multiple story lines following each of these women's lives. Moreover, Feng notes:

Since the epistler frequently cites the love affairs and worldviews of mutual acquainttances to her addressee, other women's lives and opinions are also incorporated in the letter. As such, the letter in Lu Yin's stories invariably breaks the insularity of private correspondence between two parties, conjuring up instead an intricate web of empathy and sympathy among women. [26]

Moreover, we find that Lu Yin's female protagonists not only always describe a series of their own unlucky romantic encounters with men in their letters, but also frequently refer to the similar misfortunes of their female friends in heterosexual relationships. As a result, Lu Yin's epistolary works, to some extent, employ similar tropes in order to facilitate the exchange and sharing of emotions among women. A case in point is what Jin Feng calls "her deployment of the trope of love". [26] Certainly, for Lu Yin as well as for her fictional characters, as Lee points out, to love is "an act of supreme honesty and sincerity: stripping oneself of civilised hypocrisy in order to reveal one's true self to the beloved". Also, to love is "a heroic act of defiance, renouncing all the external restraints of artificial society and merging ecstatically with nature". [27]

On the other hand, even though the romantic love is acclaimed as a symbol of supreme individualism, she constantly represented women's common experience of suffering psychological trauma caused by love in their search for both their own identity as well as the existential meaning of their life. [26]

Comparing with "Huoren de bei'ai", the narrative intensity of the protagonist's interior monologue in Feng Yuanjun's single epistolary work of fiction, “Gejue" 隔绝 (Separation, 1923), [28] lacks expressiveness. As one of her early short stories that share a central theme, "Gejue" is also about the great suffering of a young woman torn between attachment to her mother and attachment to her lover, a married man. As Lieberman points out, this type of plot structure "revolves around a terrifying eventuality": that a modern woman, in love with a man of her own choosing, might be lured against her will into a traditional arranged marriage through love for her mother. Otherwise, it also "encompasses the opposite, and perhaps equally terrifying, likelihood": that the daughter who pursues a modern existence will lose her mother in the process. [6] "Gejue" belongs to the latter.

This epistolary short story starts on the second day of the female protagonist's imprisonment by her mother. Despite her confinement, it can be seen that her room is well furnished, and her cousin has secretly given her papers and a pen, so the female protagonist named Wei Naihua is able to write the letter. Through Wei's narrative, we soon learn that her relationship with her lover, a married man named Qing Ai, is forbidden by their parents, and we also learn that she believes ardently in free love. For example, Wei Naihua denounces in the letter to her lover that:

Qing Ai! How is it that our love-so sacred, noble, and innocent-has turned into something so condemned! Life can be sacrificed, but not one's will! If I can't have my freedom, I'd prefer to die! When people don't understand that love must be sought freely, then nothing else matters... This world is a huge prison, and life is but a journey filled 
with thorns and brambles. What do I need of this world? If for some reason you were to die, how could I go on living by myself? [23]

Through the narrator's IM, it can be seen that Wei Naihua believes that their relationship is the real representative of pure and free love, and she states quite clearly that reason she has not committed suicide until now is that she has hopes that Qing Ai will come to rescue her. According to her, if she were to kill herself, her mother would send her body to the house of her arranged husband, and thus it would be her "greatest degradation". [28]

From Wei Naihua's initial reaction to his expression of love towards her, we see that she feels it improper for Qing Ai to be coming on to her. In addition, Wei Naihua does feel compelled to respect some rules of interaction between men and woman in conventional Chinese society condemning extra-marital relations. However, what makes her change her mind is the apparently increased intensity with which he loves her, declaring that he will jump into a river for her. In addition, it was important to her that he at least showed a respect for her chastity, with the ritual of leaving the last layer of clothing for her to remove. Thereby, she decides to echo this intensity by continuing to declare her intent of committing suicide herself.

The female protagonist embraces such loyalty with the so-called idea of real pure and free love; however, she still wishes to follow these rules in the relationship. This contradiction can explain Wei Naihua's continued idealisation of the relationship with Qing Ai. Properly speaking, what allows Wei Naihua to break through her uneasiness of engaging in a relationship not approved by family and society is her perception of the relationship as being perfect, an almost holy existence, proven by the willingness of both of them to sacrifice themselves for each other. The female protagonist actually cannot free herself from a mentality taught to her by the family and society that regards extra-marital relationships as inherently dirty, and can only continue on by maintaining an internal narrative that idealises her relationship with Qing Ai. [28]

Furthermore, when specifically defending the purity of their relationship, Wei Naihua says that they spent ten days together and "did nothing more than hug, kiss, and talk",[28] which implies her thoughts that by not truly having sex they proved that their romantic relationship was for entirely pure reasons, showing that she complys with the traditional notion that sex outside of marriage is indeed disgraceful. Despite the fact that Wei Naihua claims to believe in free love, she simultaneously holds traditional notions of sex.

In Wei Naihua's eyes, she must explain to Qing Ai why she is even still alive, and she asserts that she will commit suicide if she is unable to escape the very next night. Meanwhile, she thinks that if she dies she will be degraded and her body is sent to her arranged husband's household. That Naihua wholly rejects this marriage arranged by her parents and even chooses death to some extent proves that her ultimate priority is not to be with her lover, but to maintain her purity. If her goal is just to reunite with her lover, committing suicide seems to make no sense, as even after accepting the arranged marriage, she could still secretly choose to be with him.

In a sense, this reminds us of the traditional expectation of Chinese women to commit suicide after the husband's death. As we know, in ancient China, Chinese wives were sometimes encouraged to commit suicide after their husbands' death, and for the women who did so, the family would erect a stone arch (zhenjie paifang) to commemorate her heroism and to inspire other women to follow her example, which not only made women's remarriage impossible and guaranteed their purity but also was regarded as a means of avoiding societal disapproval. [29] Chinese society encouraged women to attain purity through death, implying that a woman's purity, or chastity, is more important than her life. Wei Naihua intends to prove her love and loyalty to her lover through her suicide, but she is also protecting her own conceptual purity, which is in danger due to her participation in a free love relationship.

We should also notice that in spite of forewarnings that she might be taken captive, Wei Naihua still decided to return home for a visit, which is actually based upon her extremely strong desire to retrieve the real maternal love in reality. In this letter, she explains to Qing $\mathrm{Ai}$,

I love you; I also love my mum. All the love in the world is sacred, whether between man and woman or mother and child...I have returned, despite the danger, in order that love might be fulfilled in all its aspects. But it seems that, although all love has a single basis, its manifestations are different and so contradictory as to be unable to coexist. [29]

In addition, through the narrator's monologue, her desire to fulfil love in all its aspects, as well as her belief that all love is the same in some fundamental sense, reminds us of Lu Yin's writing. While Lu Yin's female protagonists asks: why, if all love is "spiritual", can't a woman love another woman, Feng Yuanjun's female protagonists asks: why, if all love is "sacred", can't a woman enjoy the love of a man and of her mother? Yet, on the other hand, even while maintaining that all manifestations of love are equal, Wei Naihua always holds to the idea that the maternal relationship ought to be different from all others. In her IM below, for example, the narrative voice shifts from a personal voice into a communal voice:

Humans! Selfish! Although they make maternal sacrifices for others, they have no spiritual regard for them because they are so trapped in their historical circumstances! The bond between a mother and a daughter is perhaps the dearest in the world. But...even that is susceptible to this general condition! No matter what kind of relationship you are in, the one who nurtures you also controls you! [29]

Apparently, the fact has forced upon Wei Nauhua the knowledge that the maternal bond transcends idealistic reality. The reason why the mother cannot help her daughter escape is that "burdened with the weight of inherited prejudices, she is her daughter's jailor". [6] Also, according to Lieberman, for the sake of establishing a modern existence for herself, she must leave her mother behind, however strongly that "modern existence may create a need to rebond with her mother". [6]

The short story ends with the female protagonist planning a desperate, last-minute escape but feeling 
pessimistic about its chances for success. In a sequel to this short story, "Gejue zhihou" (After separation, 1924), Wei Naihua's cousin offers a posthumous account of Naihua and her lover's tragic end. However, on Wei Naihua's deathbed, she finally gains the love of both her mother and her lover. Through the act of suicide, she successfully banishes the cruel, patriarchal mother and wins back the loving mother. It completes the female protagonist's challenging relation and finally grants her wish that "love might be fulfilled in all its aspects". [28]

Through the analysis above, we find that the practice of epistolary fiction, especially monologue-esque epistolary writing, opened a new perspective for Republican women writers on exploring protagonists' innermost feelings as well as providing an existential space for their marginalised discourse. Such a narrative strategy "symbollically represents the mutual sympathy and moral support the women characters have for each other within an otherwise alienating world". [1] In other words, through the epistles, the female characters establish a connection, which might recreate a supportive and self-enclosed space of female solidarity. It seems like that they had shared an experience as intimate friends. Moreover, as Amy Dooling argues, "the multilayered text provides no entry for a male protector or saviour: indeed, it constructs the illusion of a self-contained female world secure from male intrusion, a private conversation or text for female ears and eyes only." [1]

\section{Conclusion}

Acting as a way to provide authors with a safe space for showing the protagonists' interior monologue, the epistolary and diary literary forms played a vital role in early Republican women's writing. Under this protection, or perhaps say, the deliberate camouflage, female protagonists' IM can be fully conveyed.

To be specific, through the analysis above, we see that the authors attempted to imply something through both of these narrative forms; in particular, women writers used this as a way to express the characters' IM in private situations; for another thing, the usage of epistolary or diary forms could enable women writers to avoid possible criticism or blame when they tried to express their feminist feelings or thoughts. To some extent, this private narrative form provided an existential space for their discourse. As Amy Dooling argues, it enables the author to "displace the direct plotting of women's victimization in marriage with melancholic musings and nostalgic reminiscences of the female-I who self-consciously reflects on her present quandary". [1] As a textual strategy, it is worth noting that "this shift away from the immediate scene of patriarchy in action to a more mediated interpretation of experience by women, especially as it characterises so many I-narratives of this period". [1]

Overall, in an era when men seemed to dominate the whole spectrum of public life, women writers opened a new perspective on exploring female protagonists' innermost feelings.

\section{References}

[1] Amy Dooling, Women's Literary Feminism in Twentieth-Century China (Berlin: Springer, 2005).

[2] Richard L. Barnett, Dynamics of Detour: Codes of Indirection in Montaigne, Pascal, Racine, Guilleragues (Tübingen: Gunter Narr Verlag, 1986).

[3] Cynthia Huff, "That Profoundly Female, and Feminist Genre': The Diary as Feminist Practice," Women's Studies Quarterly 17, no. 3/4 (1989): 6-14.

[4] Virginia Woolf, The Second Common Reader (New York: Harcourt Brace and World, 1932).

[5] Frances Wood, Great Books of China (London: Head of Zeus Ltd, 2017).

[6] Sally Taylor Lieberman, The Mother and Narrative Politics in Modern China (Virginia: University of Virginia Press, 1998).

[7] Lu Yin, "Fuqin" [Father], in Zhongguo xiandai zuojia xuanji [Anthology of Chinese modern writers], ed. Xiao Feng (Hongkong: sanlian shudian, 1983).

[8] Sarah Coakley, Feminism and Analytic Philosophy of Religion (Oxford: Oxford University Press, 2005).

[9] Lu Yin, "Lishi de riji" [The diary of Lishi], in Lu Yin jingdian [Lu Yin's Classics] (Beijing: Jinghua chubanshe, 2001).

[10] Ding Ling, Ding Ling wenji [The collections of Ding Ling] (Hong Kong: Huiwenge, 1972).

[11] Ling Shuhua, Ling Shuhua wencun [The anthology of Ling Shuhua] (Chengdu: Sichuan wenyi chubanshe, 1998).

[12] Cui Tao, "Wusi nüxing wenxue tongxingai zhi fanpan yu fansi" [The Study on same-sex love in May Fourth women's literature], Qiusuo 9 (2013): 165-167.

[13] Stephen Angle and Michael Slote, Virtue Ethics and Confucianism (London and New York: Routledge, 2013).

[14] Susan Sniader Lanser, Fictions of Authority: Women Writers and Narrative Voice (New York: Cornell University Press, 1992).

[15] Judith Butler, Gender Trouble: Feminism and the Subversion of Identity (New York and London: Routledge, 1990).

[16] Tze-Ian D Sang, The Emerging Lesbian: Female Same-Sex Desire in Modern China (Chicago and London: The University of Chicago Press, 2003).

[17] Simon De Beauvoir, The Second Sex, trans. H. M. Parshley (London: Picador, 1953).

[18] Lu Jun, Jingshihaisu cainüqing: Lu Yin [Lu Yin: the extraworldly emotions of a female talent] (Sichuan: Sichuan wenyi chubanshe, 1995).

[19] Leonore Hoffman and Margo Cullery, Women's Personal Narratives: Essays in Criticism and Pedagogy (New York: Modern Language Association of America, 1985).

[20] Sandra M. Gilbert and Susan Gubar, The Madwoman in the Attic: The Woman Writer and the Nineteenth-Century Literary Imagination (Connecticut: Yale University Press, 2000). 
[21] Elaine Showalter, A Literature of Their Own: British Women Novelists from Brontë to Lessing (Princeton: Princeton University Press, 2009).

[22] Li Xunan, "Zhongguo xiandai rijiti xiaoshuo lun" [On modern Chinese diary fiction], (PhD thesis, The University of Jilin, 2019).

[23] Grace S. Fong, "Gender and the Failure of Canonization: Anthologizing Women's Poetry in the Late Ming," Chinese Literature: Essays, Articles, Reviews 26 (2004): 129-149.

[24] Lu Yin, "Huoren de beiai" [A certain person's melancholy], in Zhongguo xiandai zuojia xuanji [Anthology of Chinese modern writers], ed. Xiao Feng (Hongkong: Sanlian shudian 1983).

[25] Lu Yin, "Shengli zhihou" [After victory], in Zhongguo xiandai zuojia xuanji [Anthology of Chinese modern writers], ed. Xiao Feng (Hongkong: Sanlian shudian, 1983).
[26] Jin Feng, The New Woman in Early Twentieth-century Chinese Fiction (Purdue University Press, 2004).

[27] Leo Ou-fan Lee, The Romantic Generation of Modern Chinese Writers (Harvard University Press, 1973).

[28] Feng Yuanjun, "Gejue" [Separation], trans. Janet Ng, in Writing Women in Modern China: An Anthology of Women's Literature From the Early Twentieth Century, eds. Amy D. Dooling and Kristina M. Torgeson (New York: Columbia University Press, 1998).

[29] Shuqin Cui, Gendered Bodies: Toward a Women's Visual Art in Contemporary China (Honolulu: University of Hawaii Press, 2015). 